\title{
Systemic sclerosis
}

INSERM

\section{Source}

INSERM. (1999). Orphanet: an online rare disease and orphan drug data base. Systemic sclerosis. ORPHA:90291

Systemic sclerosis (SSc) is a generalized disorder of small arteries, microvessels and connective tissue, characterized by fibrosis and vascular obliteration in the skin and organs, particularly the lungs, heart, and digestive tract. There are two main subsets of SSc: diffuse cutaneous SSc (dcSSc) and limited cutaneous SSc (IcSSc) (see these terms). A third subset of SSc has also been observed, called limited Systemic Sclerosis (ISSc) or systemic sclerosis sine scleroderma (see these terms). 